\title{
Removal of Mn and Cu Ions in Synthetic Wastewater Using Dried Cockle Shell
}

\author{
Nur Fatin Aiman Ahmad Ridzwan ${ }^{1}$, Norrahilah Abdul Aziz ${ }^{1}$, Nor Azliza Akbar ${ }^{1, *}$, Zaidi Abdul Ghani , \\ Nurakmal Hamzah ${ }^{1}$, Nur Shaylinda Mohd Zin ${ }^{3}$
${ }^{1}$ School of Civil Engineering, College of Engineering, Universiti Teknologi MARA, Cawangan Pulau Pinang, 13500 Permatang Pauh, Pulau Pinang, Malaysia
${ }^{2}$ Faculty of Applied Sciences, Universiti Teknologi MARA, Cawangan Perlis, Kampus Arau 02600 Arau, Perlis, Malaysia ${ }^{3}$ Faculty of Civil Engineering and Built Environment, Universiti Tun Hussein Onn Malaysia, 83000 Parit Raja, Batu Pahat, Johor, \\ Malaysia
}

Received May 23, 2021; Revised October 19, 2021; Accepted November 28, 2021

\section{Cite This Paper in the following Citation Styles}

(a): [1] Nur Fatin Aiman Ahmad Ridzwan, Norrahilah Abdul Aziz, Nor Azliza Akbar, Zaidi Abdul Ghani, Nurakmal Hamzah, Nur Shaylinda Mohd Zin, "Removal of Mn and Cu Ions in Synthetic Wastewater using Dried Cockle Shell," Environment and Ecology Research, Vol. 10, No. 1, pp. 31 - 43, 2022. DOI: 10.13189/eer.2022.100104.

(b): Nur Fatin Aiman Ahmad Ridzwan, Norrahilah Abdul Aziz, Nor Azliza Akbar, Zaidi Abdul Ghani, Nurakmal Hamzah, Nur Shaylinda Mohd Zin (2022). Removal of Mn and Cu Ions in Synthetic Wastewater using Dried Cockle Shell. Environment and Ecology Research, 10(1), 31 - 43. DOI: 10.13189/eer.2022.100104.

Copyright $\odot 2022$ by authors, all rights reserved. Authors agree that this article remains permanently open access under the terms of the Creative Commons Attribution License 4.0 International License

\begin{abstract}
The potential of the dried cockle shell had been studied using an adsorption experiment to determine the effectiveness of $\mathrm{Mn}$ and $\mathrm{Cu}$ removal from wastewater. A continuous batch adsorption study was carried out to determine the optimum dosage with a range of $3 \mathrm{~g}$ to $24 \mathrm{~g}$ of dried cockle shell and contact time from 15 minutes to 150 minutes. The equilibrium data for adsorption were analysed by three isotherm models (i.e., Langmuir, Freundlich, Temkin) and three kinetic models (i.e., Pseudo-First Order, Pseudo-Second Order, Elovich) to define the best correlation for each metal adsorption. The result shows that the highest percentage removal of $\mathrm{Mn}$ and $\mathrm{Cu}$ using dried cockle shells were $77.8 \%$ and $88.9 \%$, respectively, with an optimum dosage of $15 \mathrm{~g}$ and 105 minutes of optimum contact time. Among these three isotherm models, the Temkin model fitted with the equilibrium isotherm for $\mathrm{Cu}$ with the value of $\mathrm{r}^{2}$ of 0.963 , while the Langmuir model best described the experimental data for Mn with a recorded value of $\mathrm{r}^{2}$ of 0.953 . From the result, the cockle shell has the ability to adsorb heavy metals such as Mn by the process of a monolayer on the outer layer of the adsorbent and $\mathrm{Cu}$ with a Gaussian energy distribution onto a heterogeneous surface. Kinetic studies have shown that the adsorption of $\mathrm{Cu}$ and $\mathrm{Mn}$ towards the cockle shell follows Pseudo-Second Order with the determination of coefficients of 1 and 0.997, respectively.
\end{abstract}

The findings from characterisation analysis found that a high percentage of $\mathrm{CaCO}_{3}$ with $95.47 \%$ influences the adsorption of $\mathrm{Mn}$ and $\mathrm{Cu}$ from wastewater. The SEM image of dried cockle shell exhibits needle-like aragonite morphology and cubic-like calcite. Cockle shells have a great potential for removing $\mathrm{Mn}$ and $\mathrm{Cu}$ from industrial effluent. Thus, it can be used as a filter material and helps increase the economy at a modest pace by recycling low-cost waste for wastewater treatment.

Keywords Cockle Shell, Heavy Metals, Wastewater

\section{Introduction}

One of the metals that are widely produced by the metal manufacturing company is steel. Steel is a flexible alloy made up of carbon, iron and other metals for mild class production [1]. In addition, there was an abundance of steel manufactured factories that dealt with various types of metals, mainly $\mathrm{Mn}$ and $\mathrm{Cu}$. According to the Department of Environmental Malaysia, the acceptable condition for the industrial effluent by referring to the Standard Effluent of Industrial Wastewater from the Department of Environment (DOE) (Standard B) of Mn 
and $\mathrm{Cu}$ are $1.0 \mathrm{mg} / \mathrm{L}$ for both respectively. According to Varma \& Misra [2], $\mathrm{Cu}$ is widely used in textile industries as the main component for the dying process [2]. Exposure to the excessive amount of $\mathrm{Cu}$ in wastewater has adverse effects on human health, such as kidney damage, anaemia and liver cirrhosis in humans [3]. In addition, the electrolytic manufacturing activities for batteries and $\mathrm{Mn}$ ore processing activities were the main sources of the Mn contaminant in wastewater [4]. Elevated Mn contamination in wastewater can cause disturbance toward the plumbing fixture due to the accumulation of $\mathrm{Mn}^{4+}$. In addition, Mn can affect the laundering operation by staining the fabric [5]. Furthermore, the overexposure of $\mathrm{Mn}$ towards the human body can cause lung tissue problems and interference of the central nervous system [6].

Currently, a lot of techniques have been used by the previous study to treat the heavy metals from industrial wastewater, such as ion exchange, coagulation and flocculation and membrane filtration. However, these techniques are high in cost that produce sludge or large particles as the by-product of the treating process [7]. Among various heavy metals treatment technologies, the adsorption process is widely used nowadays as an alternative to the existing treatment method. It is a physicochemical method that contains high surface area and porosity characteristics of adsorbents. It involves the movement of the heavy metals towards the free space of the adsorbent [8]. The whole behaviour of the adsorption process was shown by the adsorption capacity and the efficiency of removing organic and inorganic pollutants [9]. Moreover, adsorption technology had an easier application and low cost compared to other physicochemical techniques [10]. Adsorption can produce high quality of treated effluent despite its operation flexibility [11]. The adsorption process is widely used in Malaysia in the sewerage treatment plant.

The efficiency of the adsorption process depends on the selection of adsorbent materials. Currently, the application of activated carbon and carbonised material as adsorbent media has been commonly used in treating heavy metals due to its effectiveness regardless of the high cost. Activated materials are widely used as the adsorbent by most previous studies. They resulted in high percentage removal of the adsorbate such as peanut husk charcoal, activated coconut shell, and activated rice husk [12-14]. Based on the previous studies, the adsorption capacities of activated carbon were relatively higher due to its microporous nature [12,15]. The microporous characteristic of the activated carbon provides a larger surface area compared to the inactivated materials [16]. Besides, the activated carbon was preferred in treating wastewater as the thermal desorption of the adsorbed material can result in the regeneration of the activated carbon materials [15]. However, the activated and carbonisation process of the abundant waste material had increased the cost of preparing adsorbent [12].

Several types of adsorbents, such as calcium carbonate-based material and natural minerals, have resulted in a good potential of removing heavy metals [17]. Other than that, the useless abundance of waste from the fishery sector, such as shells, had resulted in high removal performance in removing heavy metals [9].

The present study might be an alternative for water treatment infrastructure for their filtration system using low-cost material, which is dried cockleshell as the filtration media. Cockle shell is one of the low-cost materials that can be used as a type of adsorbent due to its high carbonate content with a high rate of adsorption to treat heavy metals pollutants from the industrial steel wastewater [18]. Due to the high capability of dried cockle shells to remove $\mathrm{Mn}$ and $\mathrm{Cu}$, this media is chosen as an alternative for the adsorption process of $\mathrm{Mn}$ and $\mathrm{Cu}$ removal in industrial wastewater.

\section{Materials and Methods}

\subsection{Preparation of Dried Cockle Shell}

The cockle shells (CS) were randomly collected from a few restaurants located at Taiping, Perak. CS were then brushed and washed for several times by using tap water to remove excessive dirt followed by distilled water to avoid any reaction of the water with the shell. The cleaned CS were activated at $550{ }^{\circ} \mathrm{C}$ for 40 minutes in a furnace. The activated CS were then crushed into $2.0-3.0 \mathrm{~mm}$ of size using the pestle mortar. The crushed cockle shells were transferred into the sieve pan and manually sieved to remove dust from the crushed cockle shells. Finally, the prepared CS were stored in the air-tight container prior used as an adsorbent for the removal of $\mathrm{Mn}$ and $\mathrm{Cu}$.

\subsection{Characterisation of Dried Cockle Shell}

The properties of dried cockle shells were determined in terms of surface morphology, functional groups and elemental analysis. These analyses were conducted at the Universiti Teknologi MARA, Cawangan Pulau Pinang and the equipment is listed in Table 1.

Table 1. The instrument used for characterisation study.

\begin{tabular}{|c|c|c|}
\hline Instrument & Model No & Function \\
\hline $\begin{array}{c}\text { X-Ray Fluorescence } \\
\text { (XRF) Spectrometer }\end{array}$ & SI Titan 800 & Elemental analysis of \\
\hline Scanning Electron & Hitachi TM3030 & adsorbent \\
Microscopy (SEM) & Plus & of adsorbent \\
\hline
\end{tabular}

\subsection{Preparation of Synthetic Wastewater}

Two different synthetic heavy metals solutions with the same concentration were prepared. The two heavy metals were $\mathrm{Mn}$ and $\mathrm{Cu}$, which simulated close to the actual 
concentration of the heavy metal discharge from the selected factory in Pulau Pinang. For the synthetic Mn, 3 $\mathrm{mL}$ of concentrated $\mathrm{Mn}$ were mixed with $1 \mathrm{~L}$ deionised water forming a $3 \mathrm{ppm}$ synthetic Mn solution. Meanwhile, for $3 \mathrm{ppm} \mathrm{Cu}$ synthetic solution, $3 \mathrm{~mL}$ of concentrated $\mathrm{Cu}$ were mixed with $1 \mathrm{~L}$ of deionised water, forming a $3 \mathrm{ppm}$ of $\mathrm{Cu}$ synthetic solution. The initial concentrations for both synthetic solutions were tested using Spectrophotometer DR2800 (Model HACH, 127181-D).

\subsection{Batch Equilibrium Study}

A batch adsorption study was carried out to determine the potential of dried cockle shells as an adsorbent media to remove $\mathrm{Cu}$ and $\mathrm{Mn}$ from prepared synthetic wastewater. The experiment was conducted with a varied dosage of 3 $\mathrm{g}$ to $24 \mathrm{~g}$ in $100 \mathrm{~mL}$ of synthetic solutions in each conical flask. These various dosages of dried cockleshell were mixed with the synthetic solution with a $\mathrm{pH}$ value of 4 .

For the varied $\mathrm{pH}$ experiment, the initial $\mathrm{pH}$ values of the synthetic sample were varied from $\mathrm{pH} 4$ to $\mathrm{pH} 10$ in $100 \mathrm{~mL}$ of the synthetic solutions. The initial $\mathrm{pH}$ of synthetic samples was adjusted using $1 \%$ to $2 \%$ of the $5 \mathrm{M}$ $\mathrm{NaOH}$ and $5 \mathrm{M}$ of $\mathrm{HCl}$. After that, the sample solutions were mixed with the optimum dosage obtained from varied dosage experiments. The optimum $\mathrm{pH}$ from the effect of varied $\mathrm{pH}$ values for the synthetic solution was identified by the highest percentage removal of $\mathrm{Mn}$ and $\mathrm{Cu}$ from the adsorption study.

For the varied contact time, the contact time was varied from 0 minutes to 150 minutes. The optimum dosage value from the previous experiment was used for this experiment. The samples were agitated under $250 \mathrm{rpm}$ speed using an orbital shaker for 105 minutes and allowed to settle for 60 minutes after the agitation process finished. The final concentrations of the $\mathrm{Cu}$ and $\mathrm{Mn}$ were determined using the Spectrophotometer DR 2800 (Model HACH, 127181-D).

\subsection{Analysis of Adsorption Isotherm and Kinetic Model}

\subsubsection{Adsorption Isotherm Model}

The analysis of the adsorption mechanism was carried out using Isotherm Models, namely Langmuir, Freundlich and Temkin models, to analyse the adsorption capacity of the dried cockleshell using Equation 1-3. For the Langmuir model, the linear graph of $\mathrm{C}_{\mathrm{e}} / \mathrm{q}_{\mathrm{e}}$ versus $\mathrm{Ce}$ was plotted to determine the coefficient of determination $\left(r^{2}\right)$ as expressed in Equation 1.

Langmuir model:

$$
\frac{\mathrm{C}_{\mathrm{e}}}{\mathrm{Q}_{\mathrm{e}}}=\frac{1}{\mathrm{Q}_{\mathrm{o}} \mathrm{b}}+\frac{\mathrm{C}_{\mathrm{e}}}{\mathrm{Q}_{\mathrm{o}}}
$$

Where $\mathrm{C}_{\mathrm{e}}$ is the equilibrium concentration of solution and $\mathrm{q}_{\mathrm{e}}$ is the amount of molecule adsorbed per unit weight of adsorbent (mg/g). $Q_{0}$ is the monolayer capacity of the adsorbent indicates by the number of molecules adsorbed per unit weight adsorbent. Whereas $b(\mathrm{~L} / \mathrm{mg})$ is a constant that is related to the heat of adsorption. The value of $Q_{0}$ and $\mathrm{b}$ can be determined by the intercept and slope of plotting $\mathrm{C}_{\mathrm{e}} / \mathrm{q}_{\mathrm{e}}$ versus $\mathrm{C}_{\mathrm{e}}$, respectively.

The equation of Freundlich's linear model is written in Equation (2).

$$
\operatorname{Logq}_{\mathrm{e}}=\log _{\mathrm{f}}+\frac{1}{\mathrm{n}} \log \mathrm{C}_{\mathrm{e}}
$$

Where $K_{f}$ is the isotherm constant $(\mathrm{mg} / \mathrm{g}), \mathrm{n}$ is the adsorption intensity, whereas $\mathrm{C}_{\mathrm{e}}$ is the equilibrium concentration of adsorbate $(\mathrm{mg} / \mathrm{L})$ and the qe is the amount of molecule adsorbed per unit weight of adsorbent (mg/g) [17]. $\quad \mathrm{K}_{\mathrm{f}}$ and $1 / \mathrm{n}$ are determined from the interception of the linear plot $\left(\log \mathrm{q}_{\mathrm{e}}\right.$ versus $\left.\log \mathrm{C}_{\mathrm{e}}\right)$, while $1 / \mathrm{n}$ is obtained from the gradient of the plot.

The mathematical equation of the Temkin model can be written as following Equation (3):

$$
\mathrm{q}_{\mathrm{e}}=\beta \ln \alpha_{\mathrm{T}}+\beta \ln \mathrm{C}_{\mathrm{e}}
$$

Where $\alpha_{\mathrm{T}}$ is the constant parameter for equilibrium binding $(\mathrm{L} / \mathrm{g})$, and $\beta(\mathrm{J} / \mathrm{mol})$ is the Temkin constant related to sorption heat $(\mathrm{J} / \mathrm{mol})$, which can be measured using Equation (4). Linear plot of Temkin Model was developed from $\mathrm{q}_{\mathrm{e}}$ against $\ln \mathrm{C}_{\mathrm{e}}$. The intercept and slope of the plot represent the $\beta(\mathrm{J} / \mathrm{mol})$ and $\alpha_{\mathrm{T}}(\mathrm{L} / \mathrm{mg})$

$$
\mathrm{B}=\frac{\mathrm{RT}}{\mathrm{b}}
$$

\subsubsection{Adsorption Kinetic Model}

The analysis of the adsorption kinetic interaction by the kinetic model was determined using the Pseudo-First-Order, Pseudo-Second Order and Elovich with Equation 5 -7. The linear equation of Pseudo-First Order is presented by Equation (5):

$$
\log \left(q_{e}-q_{t}\right)=\log q_{e}-K_{1} t
$$

Where $\mathrm{q}_{\mathrm{e}}$ is the amount of adsorption capacity achieved at equilibrium condition $(\mathrm{mg} / \mathrm{g})$ and $\mathrm{q}_{\mathrm{t}}$ is the adsorption capacity achieved at a time $(\mathrm{min})$ with the value of $\mathrm{k}_{1}$, which indicates the rate constant of the model $\left(\mathrm{min}^{-1}\right)$ [28].

The Pseudo-Second-Order Model is written as:

$$
\frac{\mathrm{t}}{\mathrm{q}_{\mathrm{t}}}=\frac{1}{\mathrm{~K}_{2} \mathrm{q}_{\mathrm{e}}{ }^{2}}+\frac{\mathrm{t}}{\mathrm{q}}
$$

Where $k_{2}$ is the Pseudo-Second Order constant ( $g$ $\left.\mathrm{mg}^{-1} \mathrm{~min}^{-1}\right)$. The equation of Elovich's linear model is written using expression (7).

$$
\mathrm{q}_{\mathrm{t}}=\frac{1}{\beta} \ln (\alpha \beta)+\left(\frac{1}{\beta}\right) \ln (\mathrm{t})
$$

Where a represent constant related to chemisorption rate, and $\beta$ is a constant which depicts the extent of surface coverage. 


\section{Results and Discussion}

\subsection{Characterisation of Dried Cockle Shell}

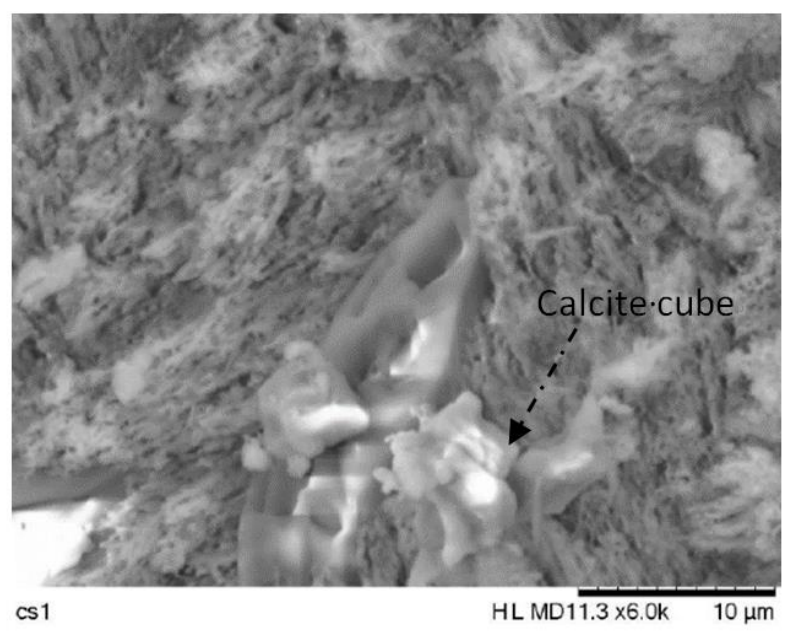

Figure 1. SEM Images of Raw Cockle Shell

Table 2. Chemical Composition of Dried Cockle Shell

\begin{tabular}{|c|c|}
\hline Compound & Concentration (wt \%) \\
\hline $\mathrm{MgCO}_{3}$ & 1.9254 \\
\hline $\mathrm{Al}_{2} \mathrm{O}_{3}$ & 0.4095 \\
\hline $\mathrm{SiO}_{2}$ & 1.3269 \\
\hline $\mathrm{P}_{2} \mathrm{O}_{5}$ & 0.0613 \\
\hline $\mathrm{SO}_{3}$ & 0.5624 \\
\hline $\mathrm{K}_{2} \mathrm{O}$ & 0.0502 \\
\hline $\mathrm{CaCO}_{3}$ & 95.4726 \\
\hline $\mathrm{TiO}_{2}$ & 0.0093 \\
\hline $\mathrm{MnO}$ & 0.0092 \\
\hline $\mathrm{Fe}_{2} \mathrm{O}_{3}$ & 0.2344 \\
\hline
\end{tabular}

Surface morphology of the raw cockle shell was examined under SEM, as shown in Figure 1. It was observed that aragonite, a needle-like structure found in natural cockle shells and calcite with a hexagonal shape. According to [19], calcite cube-like crystals are much more stable than aragonite rod-like orthorhombic crystals. According to XRF analysis as shown in Table 2, raw cockle shell contains $95.47 \% \mathrm{CaCO}_{3}, 1.93 \% \mathrm{MgCO}_{3}, 1.33 \%$ $\mathrm{SiO}_{2}, 0.562 \% \mathrm{SO}_{3}, 0.401 \% \mathrm{Al}_{2} \mathrm{O}_{3}$. The result shows that the cockle's shell that is high in calcite can help with ion exchange and adsorption processes. Aragonite $\mathrm{CaCO}_{3}$ is one of the orthorhombic polymorphs of $\mathrm{CaCO}_{3}$ other than calcite and vaterite found in raw cockle shells. Cockle shell is made up of $\mathrm{CaCO}_{3}$, which is one of the sources of $\mathrm{CaO}$. The findings supported by [20] and [21] claim that cockle shells contain a large amount of calcium oxide. $\mathrm{CaCO}_{3}$ will be decomposed to $\mathrm{CaO}$ when exposed to high temperatures at $700{ }^{\circ} \mathrm{C}$ or above [21]. Besides removing heavy metals, calcium oxide can be used as a $\mathrm{pH}$ booster due to its ability to generate hydroxide groups in water [22].

\subsection{Batch Adsorption Experiment}

\subsubsection{Effect of Varied Dosage}

The batch adsorption experiment was carried out in this research to identify the potential of the cockleshell as adsorbent media to remove heavy metals from industrial wastewater. In this study, the effect of varied dosage, $\mathrm{pH}$ and contact time was investigated. Figure 2 shows the plot of the percentage removal of both $\mathrm{Mn}$ and $\mathrm{Cu}$ concentrations for varied dosage experiments. The highest removal percentages of both $\mathrm{Mn}$ and $\mathrm{Cu}$ from the adsorbate was $84.8 \%$ and $92.9 \%$, respectively, at $15 \mathrm{~g}$ of dried cockle shell in $100 \mathrm{~mL}$ of the synthetic sample. The percentage removal for both metals tends to be increased until the optimum dosage is identified. This is due to the available porous space on the dried cockle shell that helps to adsorb the $\mathrm{Mn}$ and $\mathrm{Cu}$ molecule [23]. As plotted in Figure 2, the percentage removal for both metals was gradually increased with the maximum dosage of 15 grams of adsorbent and decreased after more than 18 grams of adsorbent was applied.

The desorption process occurs due to the unavailable of free space for the molecule to undergo adsorption, which limits the capacity of the dried cockle shell as an adsorbent media. Based on the previous study done by Budin et al. (2014)], the optimum dose resulted from the study of treating lead $(\mathrm{Pb})$ metal using raw cockle shell was $1.0 \mathrm{~g}$ with a percentage removal of $68.0 \%$ at 90 minutes contact time. On the contrary, in this study, the $550{ }^{\circ} \mathrm{C}$ dried cockleshell was able to treat $\mathrm{Mn}$ and $\mathrm{Cu}$ at a dosage of $15 \mathrm{~g}$ cockleshell with the percentage removal of $84.8 \%$ and $92.9 \%$ for $\mathrm{Mn}$ and $\mathrm{Cu}$, respectively. This indicates that the reduction of $\mathrm{Mn}$ and $\mathrm{Cu}$ concentration from the synthetic sample using the $550{ }^{\circ} \mathrm{C}$ dried cockle shell was higher compared to the raw cockle shell done by the previous study. 


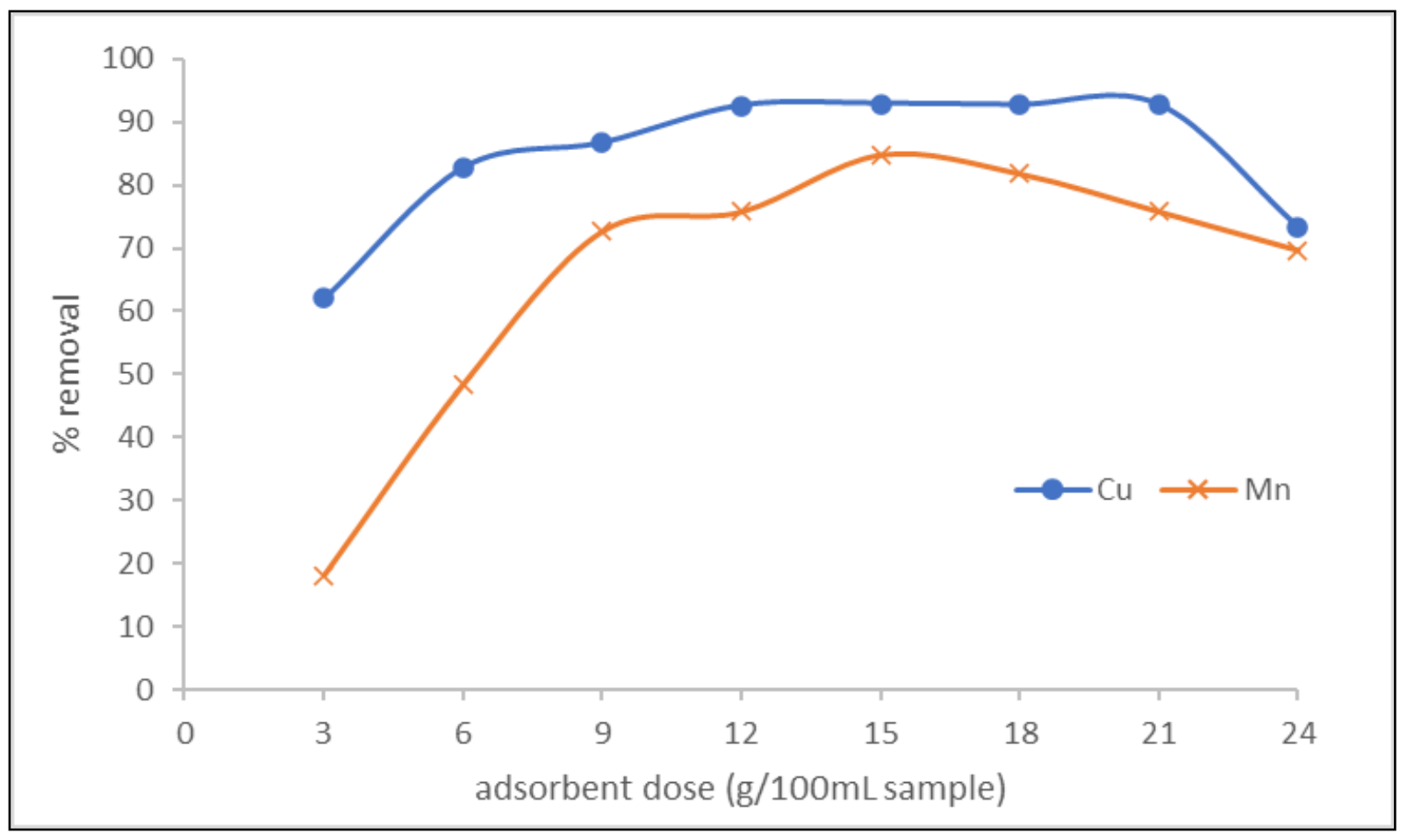

Figure 2. Removal of $\mathrm{Mn}$ and $\mathrm{Cu}$ concentration against varied dosage of adsorbent

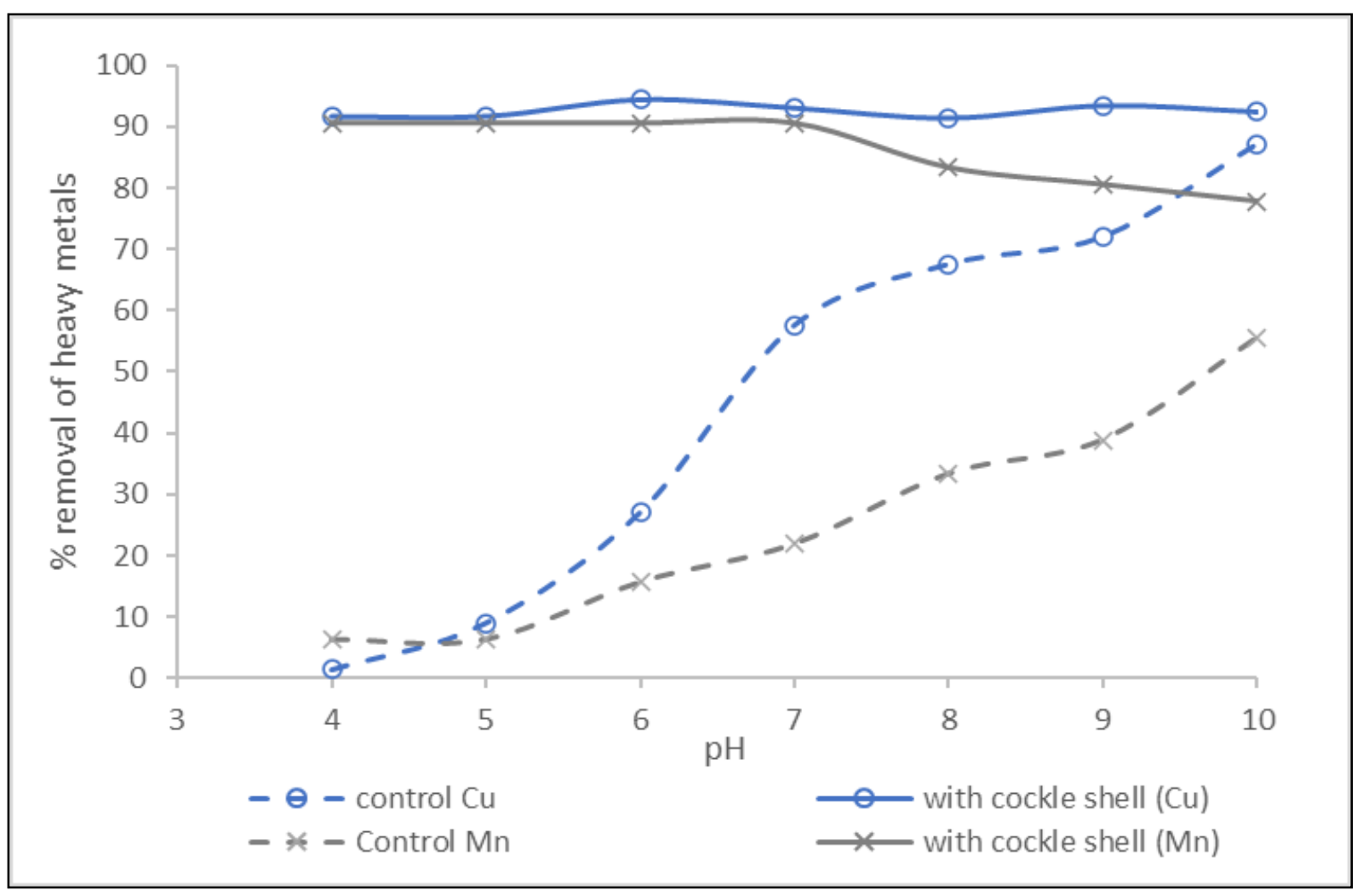

Figure 3. Removal of $\mathrm{Mn}$ and cu concentration against varied $\mathrm{pH}$

\subsubsection{Effect of Varied $\mathrm{pH}$}

Figure 3 shows the actual percentage removal of $\mathrm{Mn}$ and $\mathrm{Cu}$ for varied $\mathrm{pH}$ studies.

The highest percentage removal of Mn occurs at $\mathrm{pH} 4$, which was $84.3 \%$ after reducing the percentage removal for the presence of adsorbent with the percentage removal of the control experiment. At the same time, the highest percentage of $\mathrm{Cu}$ removal after subtracting both control 
and prepared adsorbent values was $90.4 \%$. Nevertheless, the actual percentage removal for both $\mathrm{Mn}$ and $\mathrm{Cu}$ adsorbate decreased as the $\mathrm{pH}$ value was increased from $\mathrm{pH} 5$ to $\mathrm{pH} 10$ due to the decreasing amount of $\mathrm{H}^{+}$ molecules on carbon surface when subjected to high $\mathrm{pH}$ value and alkaline conditions. The high amount of hydrogen ions was believed to strengthen the electrostatic attraction between the adsorbate and the positively charged adsorbent [24]. The higher adsorption of $\mathrm{Cu}$ that took place in alkaline condition that caused the surface of cockle shell to become more negative. The negative charge on the cockle shell provided electrostatic interactions to adsorb cation species [25]. Electrostatic attraction between anionic surface group of cockle shell and cationic metals was suggested to contribute to the adsorption of $\mathrm{Mn}$ and $\mathrm{Cu}$ by cockle shell.

Besides, the present of $\mathrm{OH}^{-}$in alkaline condition caused reaction with metal ions to form precipitates [26]. Result from the batch adsorption experiment found that the adsorption mechanisms of $\mathrm{Mn}$ and $\mathrm{Cu}$ by cockle shell occur due to ion exchange and surface precipitation. Ion-exchange mechanism on the $\mathrm{CaCO}_{3}$ material into solution are expressed in the equation (8) and (9).

$$
\begin{gathered}
-\mathrm{CaCO}_{3}+\mathrm{Mn}^{2+} \rightarrow-\mathrm{CaCO}_{3} \mathrm{Mn}+\mathrm{Ca}^{2+} \\
-\mathrm{CaCO}_{3}+\mathrm{Cu}^{2+} \rightarrow-\mathrm{CaCO}_{3} \mathrm{Cu}+\mathrm{Ca}^{2+}
\end{gathered}
$$

\subsubsection{Effect of Varied Contact Time}

Besides, one of the important factors that influenced the removal rate of the cockle shell was the contact time of the process. The optimum contact time required for both heavy metals onto dried cockle shells was investigated. Figure 4 shows the relationship between dried cockle shells and heavy metals $(\mathrm{Mn}$ and $\mathrm{Cu})$ in a series of reaction times. Based on the plot, the highest percentage removal of both $\mathrm{Mn}$ and $\mathrm{Cu}$ were $77.8 \%$ and $88.9 \%$ at an optimum contact time of 105 minutes, respectively. The plotted graphs exhibit rapid $\mathrm{Mn}$ and $\mathrm{Cu}$ adsorption in the 15 minutes of the experiments, with the removal of $\mathrm{Mn}$ and $\mathrm{Cu}$, increased up to $55.6 \%$ and $80.6 \%$, respectively. Moreover, there were increased gradually of percentage removal for both metals between 15 minutes to 105 minutes as the optimal condition were applied for the majority condition. After 105 minutes of reaction time, the percentage removal for both metals tends to decrease due to the lack of space of active sites for the adsorption to take place [27]. The adsorption process had achieved an equilibrium condition at 120 minutes for $\mathrm{Mn}$ resulted in no further reduction of $\mathrm{Mn}$ metal concentration. At the equilibrium condition, it indicated that the maximum capacity of the dried cockle shell had been used in that particular contact time [28].

Figure 4 illustrates the adsorption capacity of $\mathrm{Mn}$ and $\mathrm{Cu}$ by cockle shells subjected to varied contact times. It was found that the highest capacity of adsorbent was at
105 minutes with the maximum adsorption capacity, qe of $0.0166 \mathrm{mg} / \mathrm{g}$ and $0.014 \mathrm{mg} / \mathrm{g}$ for both $\mathrm{Mn}$ and $\mathrm{Cu}$, respectively. However, the capacity for removing both metals decreased after the process reached the equilibrium phase after 105 minutes. According to Mojiri et al. [29] the result found that the cockle shell powder adsorbent had a higher adsorption capacity of $0.975 \mathrm{mg} / \mathrm{g}$ in removing Molybdenum metals compared to this present study. The difference between the adsorption capacity for both current and previous studies was due to the larger cockle shell with particle size in the range of $2-3.35 \mathrm{~mm}$ used in this study having a smaller surface area, resulting in less adsorption capacity the powdered cockleshell [30].

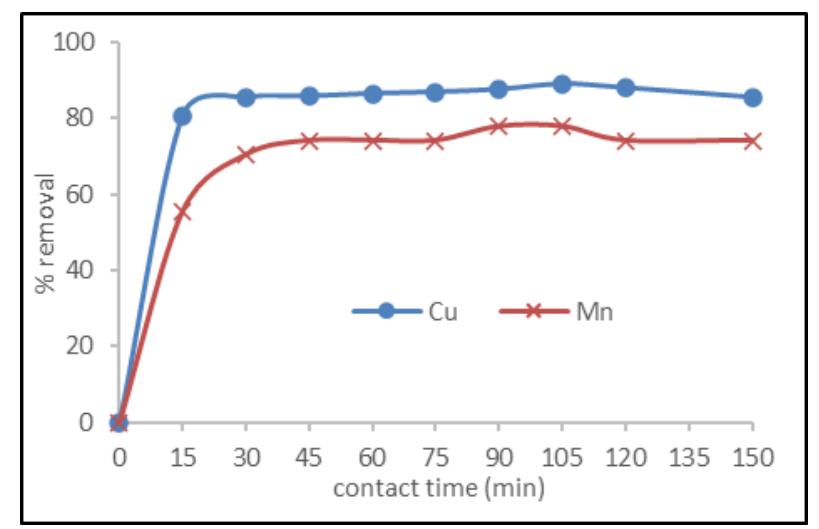

Figure 4. Removal of $\mathrm{Mn}$ and $\mathrm{Cu}$ concentration against varied contact time of adsorbent

\subsection{Adsorption Isotherm Model}

Adsorption isotherm is a crucial step to understand the relationship between adsorbents and target pollutants. The distribution of the adsorbate onto the surface of the adsorbent was quantified by the linear regression analysis [31]. In this study, the experimental data from the adsorption of $\mathrm{Mn}$ and $\mathrm{Cu}$ by dried cockle shells were explored using three equilibrium isotherm models, i.e., Langmuir, Freundlich and Temkin.

Figure 5 and Figure 6 show the linear regression plot of $\mathrm{Mn}$ and $\mathrm{Cu}$ adsorption using dried cockle shells by Langmuir, Freundlich and Temkin isotherm models. From the linear regression plot, the coefficient of determination $\left(\mathrm{r}^{2}\right)$ values for all models were determined, and the best isotherm model was selected based on the highest value of $r^{2}$. The $r^{2}$ value recorded for the Langmuir model in Figure 5, which was 0.933, stipulated that the design for the adsorption process of Mn by dried cockle shell was matched with the Langmuir model. Similarly, a previous study regarding the adsorption process of Mn removal using activated zeolite was fitted the Langmuir model with an $r^{2}$ value of 0.972 [32]. Despite the lower value of $r^{2}$, i.e., 0.604, the Freundlich model has not suited the pattern of the adsorption process. 


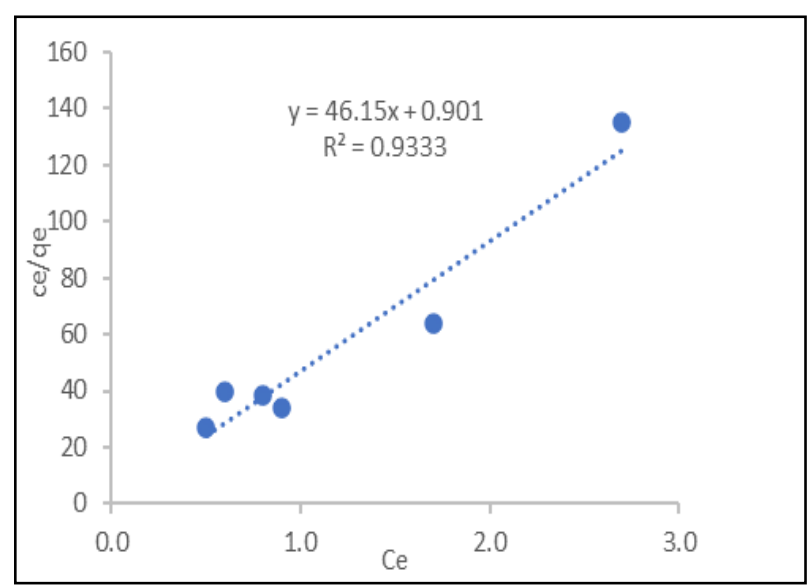

(a)

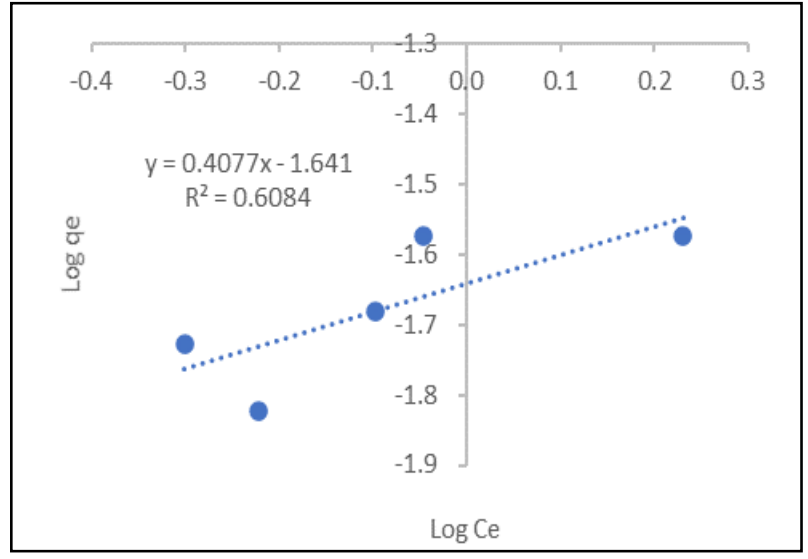

(b)

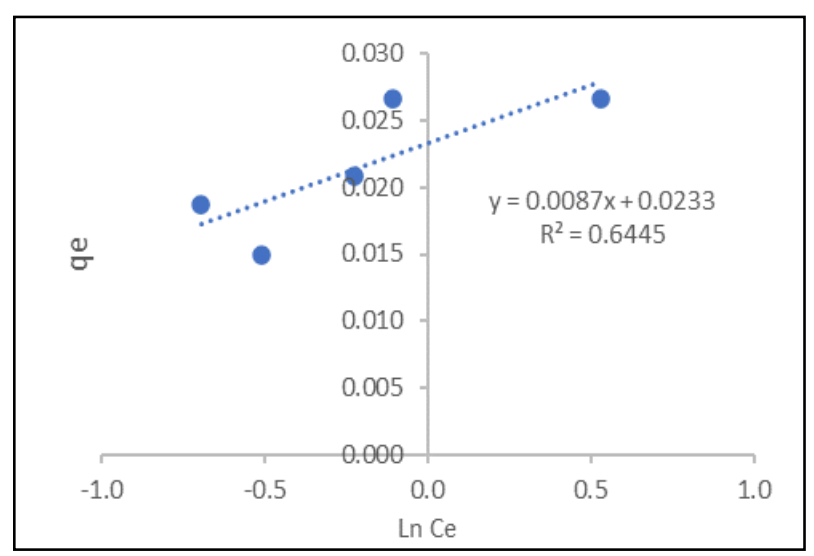

(c)

Figure 5. Adsorption isotherm modelling for Mn adsorption; a) Langmuir, b) Freundlich, c) Temkin

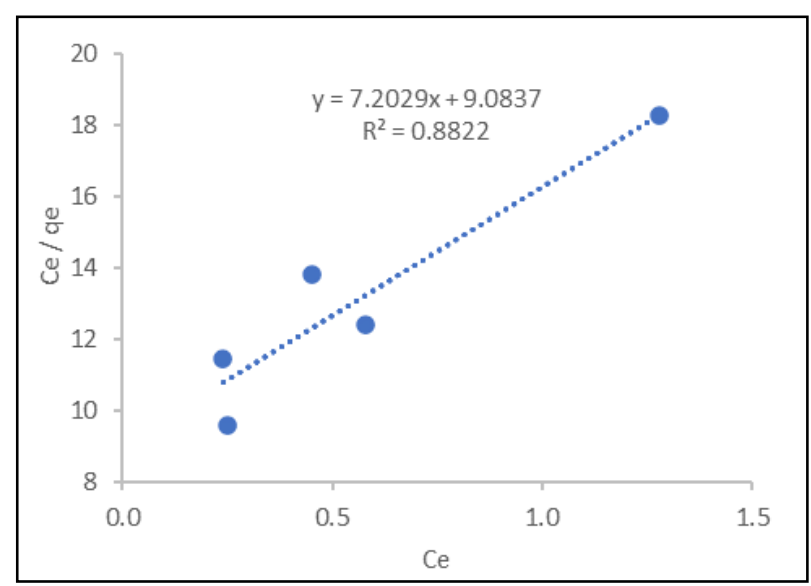

(a)

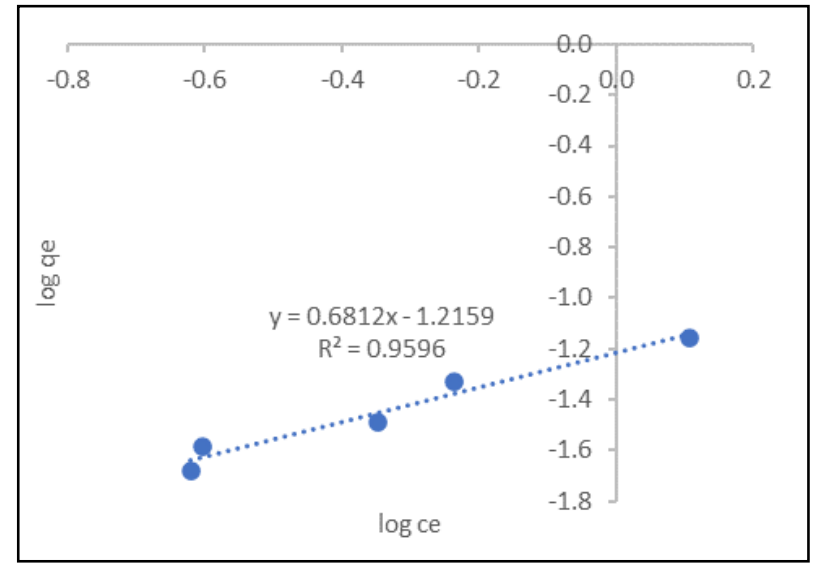

(b)

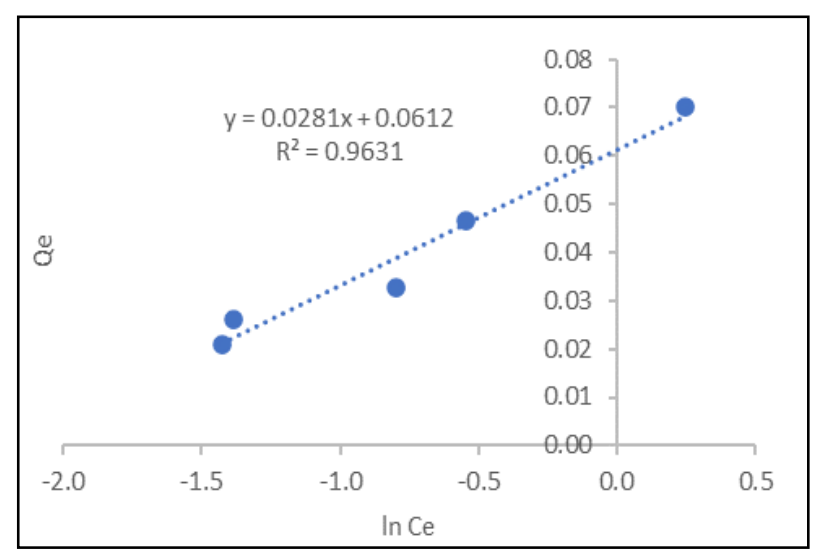

(c)

Figure 6. Adsorption isotherm modelling for $\mathrm{Cu}$ adsorption; a) Langmuir, b) Freundlich, c) Temkin 
Figure 6 interprets the Langmuir, Freundlich and Temkin isotherm models of the $\mathrm{Cu}$ adsorption process by cockle shells. The result from the effect of the varied contact time experiment was plotted and identified for the best model that fit the adsorption of $\mathrm{Cu}$ by cockle shell. The suitability of adsorption isotherm models to present the experimental data for $\mathrm{Cu}$ in accordance to $\mathrm{r}^{2}$ value can be arranged as follows: Temkin (0.963) > Freundlich (0.969)> Langmuir (0.882).

Table 3. Summary results of the constant parameters of the adsorption isotherm model for cockle shell

\begin{tabular}{|c|c|c|}
\hline Isotherm model & Mn & $\mathbf{C u}$ \\
\hline \multicolumn{3}{|c|}{ Langmuir } \\
\hline$r^{2}$ & 0.933 & 0.882 \\
\hline $\mathrm{Q}(\mathrm{mg} / \mathrm{L})$ & 0.022 & 0.139 \\
\hline $\mathrm{b}$ & 51.221 & 0.793 \\
\hline \multicolumn{3}{|c|}{ Freundlich } \\
\hline$r^{2}$ & 0.604 & 0.959 \\
\hline $\mathrm{n}$ & 2.453 & 1.468 \\
\hline $\mathrm{K}_{\mathrm{f}}$ & 0.023 & 0.061 \\
\hline \multicolumn{3}{|c|}{ Temkin } \\
\hline$r^{2}$ & 0.645 & 0.963 \\
\hline$\alpha_{\mathrm{T}}$ & 14.558 & 8.828 \\
\hline$\beta$ & 280143 & 86735 \\
\hline
\end{tabular}

Table 3 present the summary of these isotherm models for $\mathrm{Mn}$ and $\mathrm{Cu}$ adsorption. The $\mathrm{R}_{\mathrm{L}}$ value for both $\mathrm{Mn}$ and $\mathrm{Cu}$ were 0.230 and 0.267 , respectively, which were less than 1 , and it shows that both metals were favourable towards the Langmuir model [17]. Based on the Freundlich data, the adsorption intensity, i.e., the $\mathrm{N}$ value for $\mathrm{Mn}$ and $\mathrm{Cu}$, were 2.453 and 1.468 , respectively. The $\mathrm{N}$ value for both metals, which were greater than one, indicated that the $\mathrm{Mn}$ and $\mathrm{Cu}$ undergo good adsorption [33], and the sorption intensity is good for a wide range of pollutant concentrations. The suitability of the Langmuir model for the Mn was supported by the higher value of the coefficient of determination $\left(\mathrm{r}^{2}=0.933\right)$ compared to the Freundlich model $\left(r^{2}=0.604\right)$ and Temkin $\left(r^{2}=0.645\right)$. From this result, it was found that the Mn carried out the process with monolayer adsorption. This mechanism is usually completed by binding the solute molecule onto dried cockle shell adsorbent surface through chemisorption reaction. On the contrary, the Temkin model is the best model $\left(r^{2}=0.963\right)$ to identify the $\mathrm{Cu}$-dried cockle shell adsorbent interaction in this study.
This model describes the adsorption mechanism through the energy value required for the adsorption of pollutants onto the surface of the dried cockle shell.

\subsection{Adsorption Kinetic Model}

Kinetic models are important to identify the dynamic mechanism of adsorbate toward the adsorbent. Three different models were used to determine the suitable kinetic model for the adsorption of $\mathrm{Mn}$ and $\mathrm{Cu}$ by the data resulting from the batch adsorption experiment with the effect of varied contact time. The linear regression plots for both models were based on adsorbate per unit mass of adsorbent $(\mathrm{mg} / \mathrm{g})$ at certain contact time data from the experiment. Figure 7 and Figure 8 present the kinetic model of $\mathrm{Mn}$ and $\mathrm{Cu}$ using cockle shell respectively. Moreover, Table 4 shows the summary of the constant parameter and the coefficient of determination for both adsorption kinetic models for $\mathrm{Mn}$ and $\mathrm{Cu}$ by dried cockle shells. The suitability of both $\mathrm{Mn}$ and $\mathrm{Cu}$ toward the Pseudo-Second Order model was shown by the high value of $\mathrm{r}^{2}$, which were 0.997 and 1 for both $\mathrm{Mn}$ and $\mathrm{Cu}$ adsorption type, respectively, compared to the $r^{2}$ value of Pseudo-First Order kinetic model. The $\mathrm{q}_{\exp }$ results for both $\mathrm{Mn}$ and $\mathrm{Cu}$ at equilibrium time were $0.0166 \mathrm{mg} / \mathrm{g}$ and $0.014 \mathrm{mg} / \mathrm{g}$, respectively. The kinetic adsorption of $\mathrm{Mn}$ and $\mathrm{Cu}$ were suitable with the Pseudo-Second Order model as the value of $\mathrm{q}_{\text {cal }}$ were closed to the $\mathrm{q}_{\mathrm{exp}}$ for both $\mathrm{Mn}$ and $\mathrm{Cu}$ with a value of $0.0144 \mathrm{mg} / \mathrm{g}$ and $0.0166 \mathrm{mg} / \mathrm{g}$. This is similar to a previous study [34] on the adsorption of Mn metal using rice husk ash.

A study [35] found that the adsorption of $\mathrm{Mn}$ and $\mathrm{Cu}$ using orange peel from aqueous solution followed the Pseudo-Second Order kinetic model with rate constant, $\mathrm{k}_{2}$ value of 0.17 and 1.50 for the $\mathrm{Mn}$ and $\mathrm{Cu}$, respectively. Despite the higher value of the rate constant, $\mathrm{k}_{2}$ of $\mathrm{Mn}$ and $\mathrm{Cu}$ (calculated from Equation 6) for this experiment using the dried cockle shell were 3.652 and 6.504, which indicates that the speed of the adsorption process carried out using the dried cockle shell were faster compared to the orange peel. In addition, it was found that the dried cockle shell had a stronger chemical interaction with the adsorbent due to its high calcium carbonate content with the presence of $\mathrm{O}-\mathrm{H}$ bonding [36] compared to the orange peel done by a previous study.

The analysis found that both $\mathrm{Mn}$ and $\mathrm{Cu}$ adsorption followed the Pseudo-Second Order kinetic model. This result indicates that the adsorption of both $\mathrm{Mn}$ and $\mathrm{Cu}$ is carried out by chemical adsorption or known as chemisorption. Chemisorption occurred as their strong hydrogen interaction creating ionic and covalent bonding on the adsorbent surface at low concentrations [37]. 


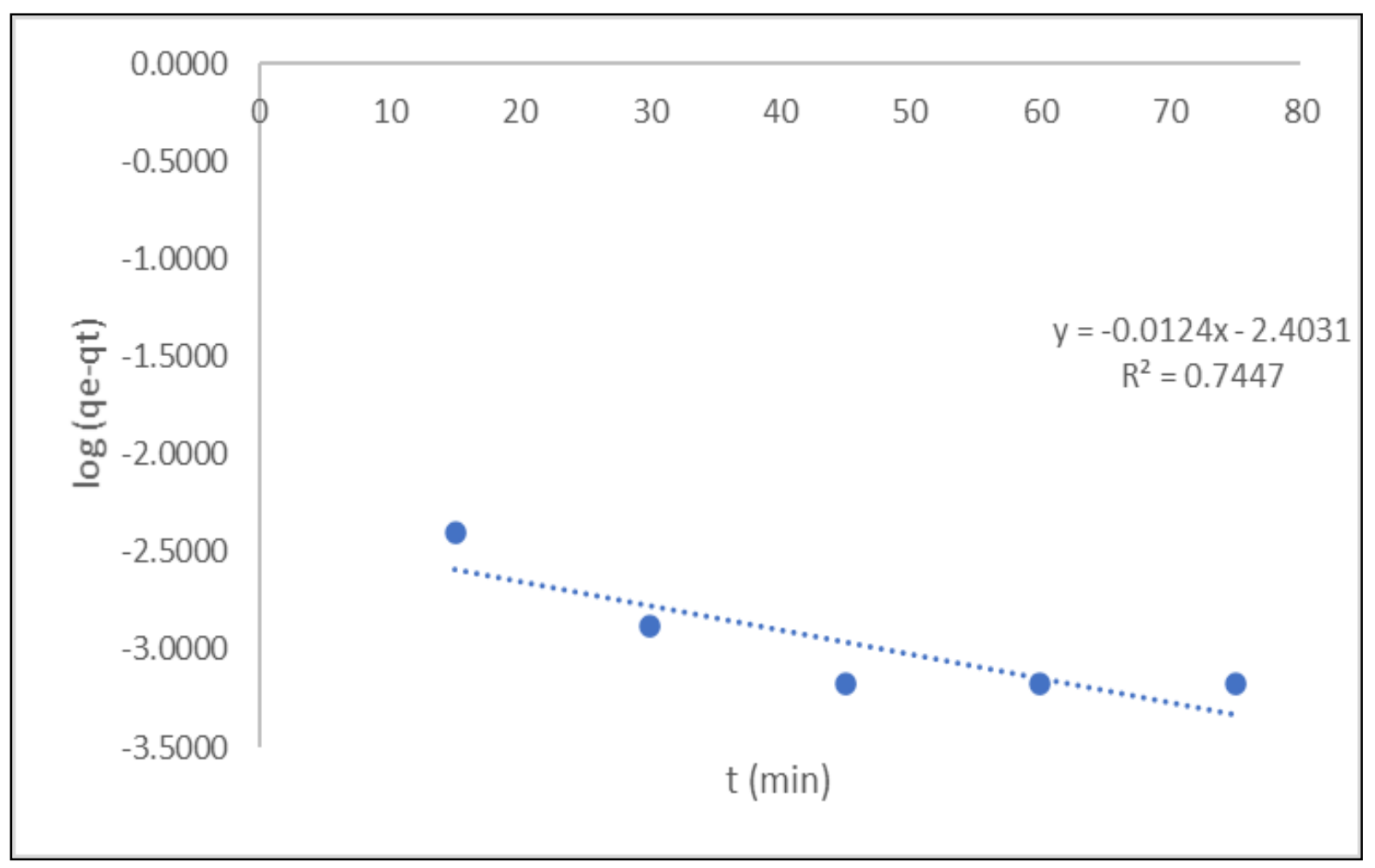

(a)

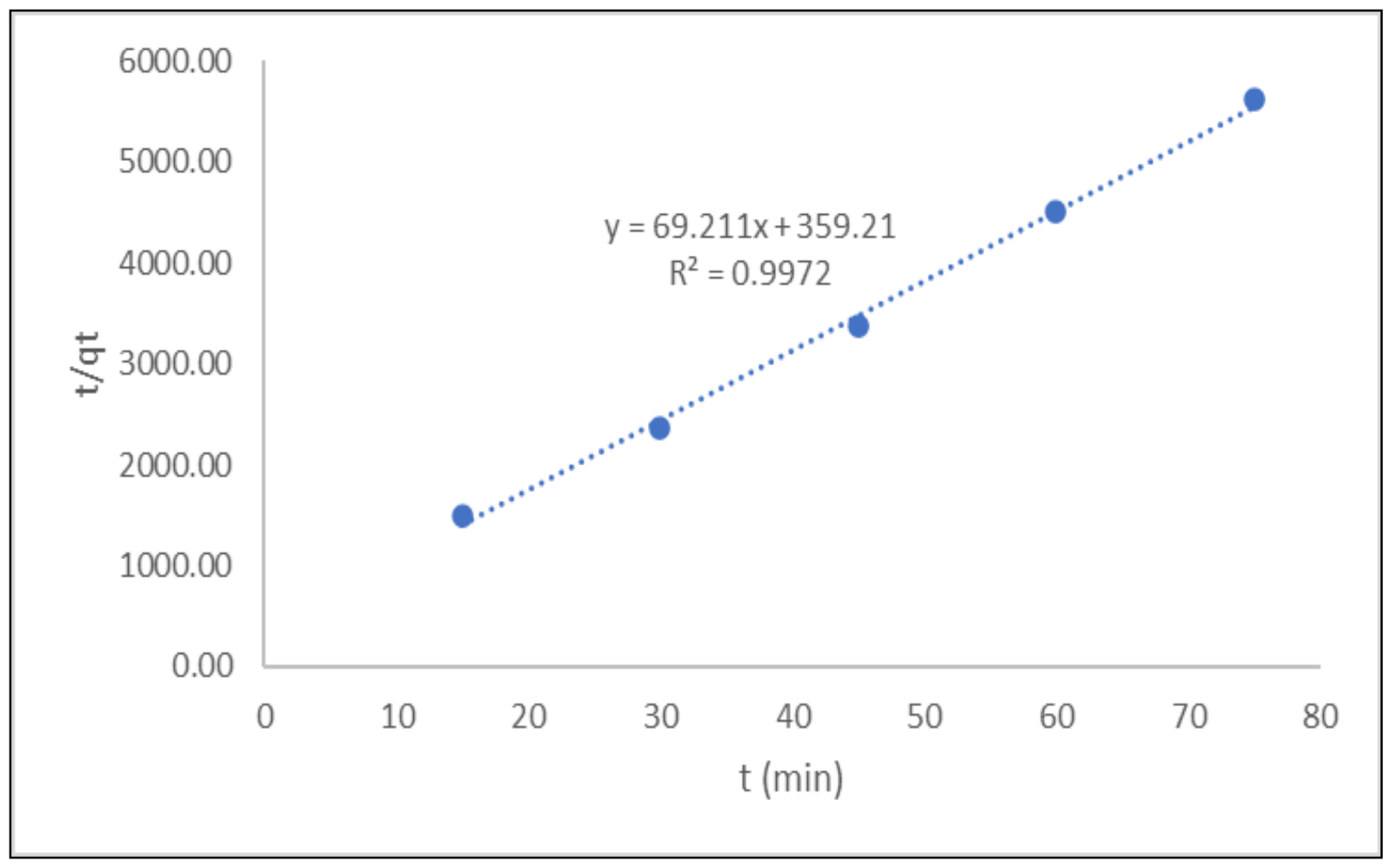




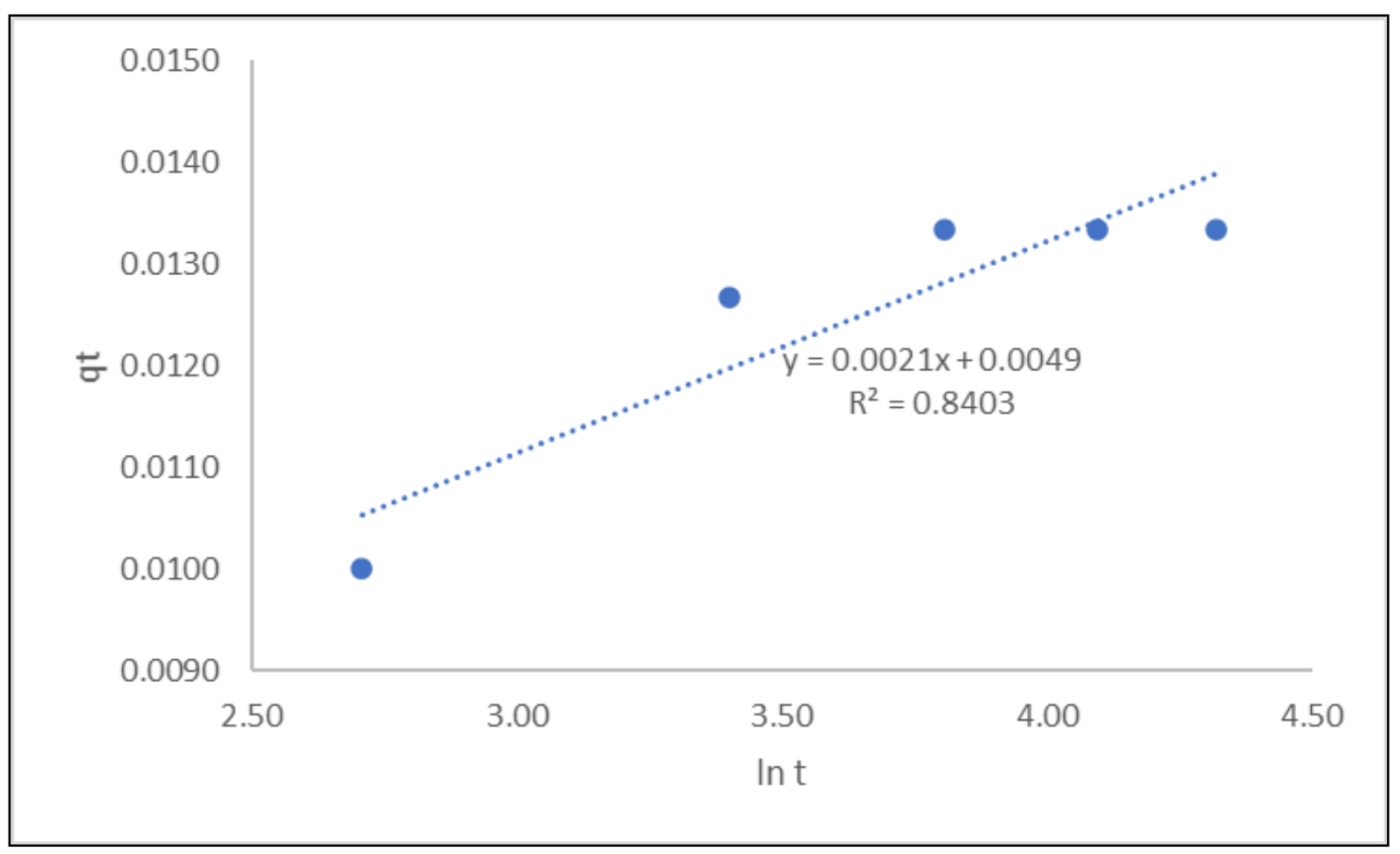

(c)

Figure 7. Adsorption kinetic modelling for Mn adsorption; a) Pseudo First Order, b) Pseudo Second Order, c) Elovich

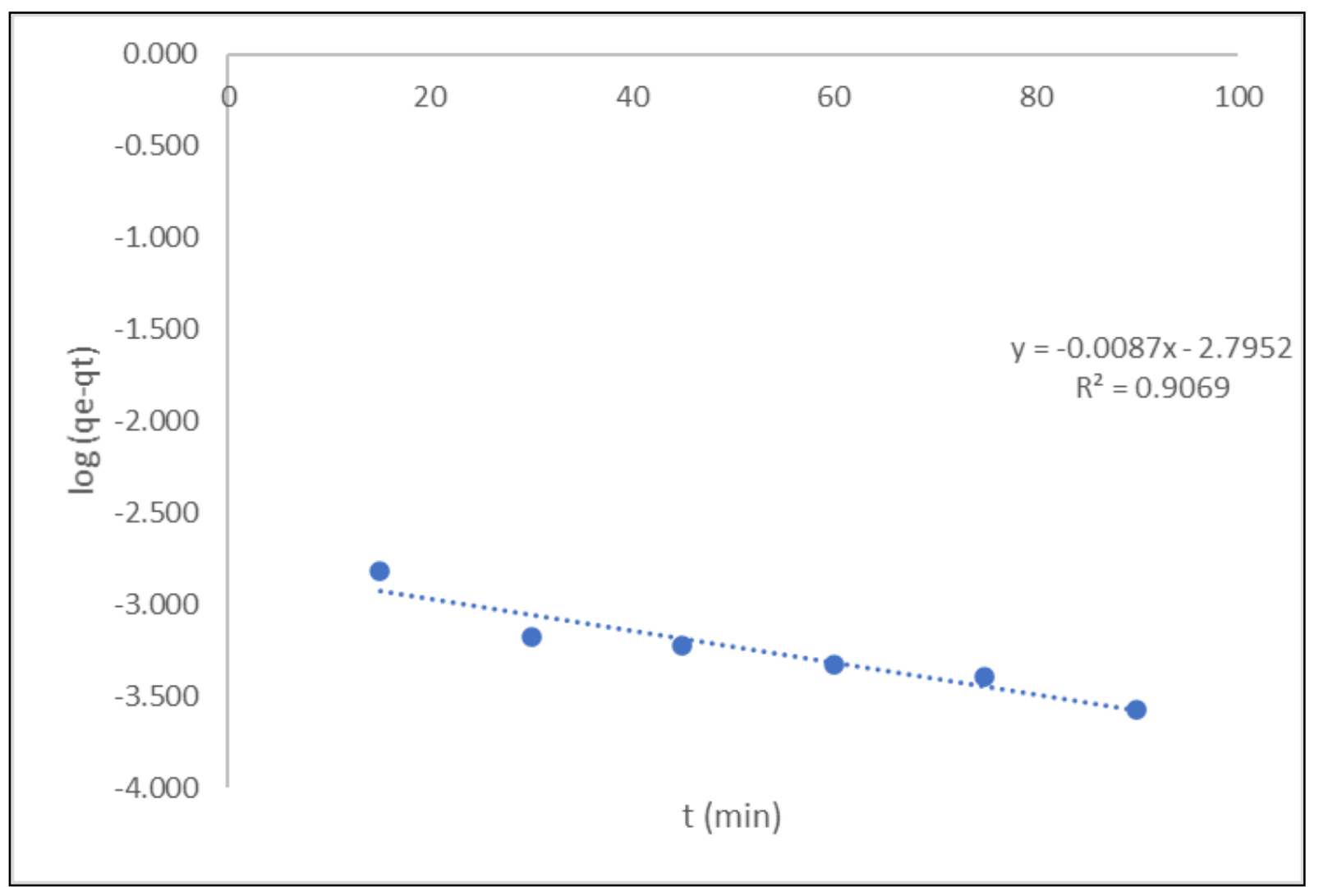

(a) 


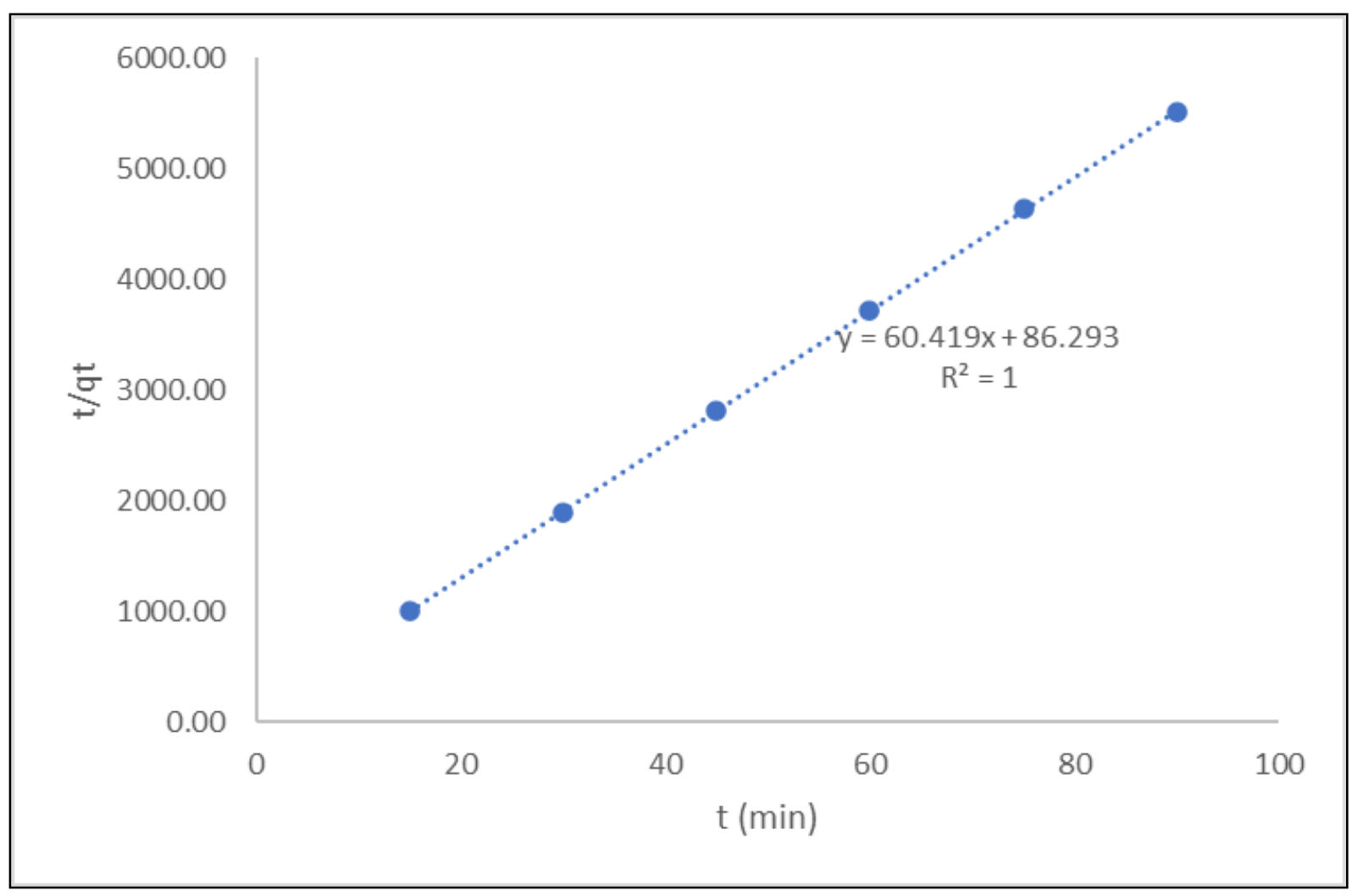

(b)

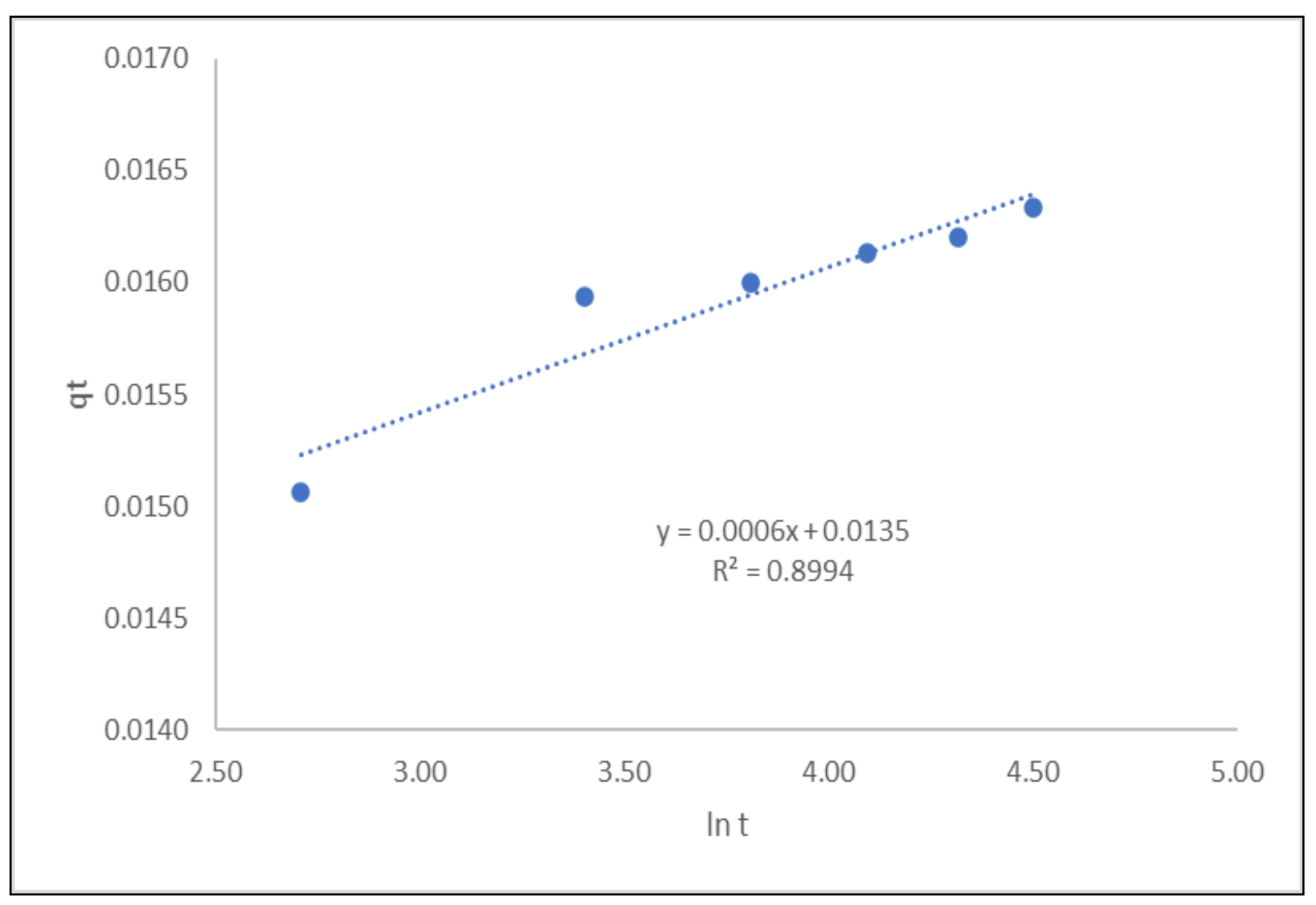

(c)

Figure 8. Adsorption kinetic modelling for $\mathrm{Cu}$ adsorption; a) Pseudo First Order, b) Pseudo Second Order, c) Elovich 
Table 4. Summary results of the constant parameters of the adsorption kinetic model for cockle shell

\begin{tabular}{|c|c|c|}
\hline Kinetic model & Mn & Cu \\
\hline $\mathrm{q}_{\mathrm{e}, \text { exp }}$ & 0.014 & 0.0166 \\
\hline \multicolumn{3}{|c|}{ Pseudo- First Order } \\
\hline $\mathrm{r}^{2}$ & 0.745 & 0.907 \\
\hline $\mathrm{k}_{1}$ & 0.0124 & -0.0087 \\
\hline $\mathrm{q}_{\mathrm{e}, \mathrm{calc}}$ & 0.004 & 0.001603 \\
\hline \multicolumn{3}{|c|}{ Pseudo Second Order } \\
\hline $\mathrm{r}^{2}$ & 0.997 & 1 \\
\hline $\mathrm{k}_{2}$ & 3.652 & 6.504 \\
\hline $\mathrm{q}_{\mathrm{e}, \text { calc }}$ & 0.0144 & 0.0166 \\
\hline & Elovich \\
\hline $\mathrm{r}^{2}$ & 0.840 & 0.899 \\
\hline$\alpha$ & 0.0217 & $3.546 \times 10^{6}$ \\
\hline$\beta$ & 476.19 & $1.667 \times 10^{3}$ \\
\hline $\mathrm{q}_{\mathrm{e}, \mathrm{calc}}$ & 0.0106 & 0.0151 \\
\hline & &
\end{tabular}

\section{Conclusions}

In conclusion, dried cockle shells have a high potential to remove $\mathrm{Mn}$ and $\mathrm{Cu}$ from industrial wastewater. The use of cockle shells can be applied as a filter media to reduce the abundance waste of cockle shells with lower cost needed. Based on the results obtained, the highest percentage of $\mathrm{Mn}$ and $\mathrm{Cu}$ removal was recorded at $84.8 \%$ and $92.9 \%$, respectively, with $15 \mathrm{~g}$ of dried cockle shell used and 105 minutes contact time. The adsorption process of Mn suits the Langmuir isotherm model with an $\mathrm{r}^{2}$ value of 0.953 , whereas the adsorption process of $\mathrm{Cu}$ fits the Temkin isotherm model with a value of 0.963 . Moreover, the rate of kinetic adsorption for both $\mathrm{Mn}$ and $\mathrm{Cu}$ followed the Pseudo-Second Order kinetic model. The suitability of Pseudo-Second Order models was strongly supported by the higher value of $\mathrm{q}_{\mathrm{cal}}$ and $\mathrm{q}_{\mathrm{exp}}$ for both $\mathrm{Mn}$ and $\mathrm{Cu}$, which were $0.0144 \mathrm{mg} / \mathrm{g}$ and $0.0166 \mathrm{mg} / \mathrm{g}$, respectively, compared to the Pseudo-First Order model. This result indicates that the adsorption process was done by chemisorption, which is related to the strong ionic and covalent between the dried cockle shell and the adsorbate. Hence, the dried cockle shells have great potential and are capable of removing heavy metals from industrial wastewater. In addition, it can overcome the problem of abundance of cockle shell waste by recycling it, which complies with the concept of waste minimisation, i.e., 3R concept.

\section{Acknowledgements}

The authors would like to express their gratitude to the Faculty of Civil Engineering, Universiti Teknologi
MARA, Cawangan Pulau Pinang, for their support in completing this research.

\section{REFERENCES}

[1] C. R. D. F. Azevedo, \& A.F. Padilha, "The most frequent failure causes in super ferritic stainless steels: are they really super?.", Procedia Structural Integrity 17, 331-338, 2019.

[2] V.G.Varma, \& A.K. Misra, "Copper contaminated wastewater-An evaluation of bioremedial options. Indoor and Built Environment", 27(1), 84-95, 2018.

[3] O.B. Akpor., D.A. Otohinoyi, D.T.Olaolu, \& B.I. Aderiye, "Pollutants in wastewater effluents: impacts and remediation processes", International Journal of Environmental Research and Earth Science, 3(3), 050-059, 2014.

[4] Y. Li, Z. Xu, H.Ma, \& S.A. Hursthouse, "Removal of Mn (II) from Acid Mine Wastewater: A Review of the Challenges and Opportunities with Special Emphasis on Mn-Oxidizing Bacteria and Microalgae", Water, 11(12), 2493, 2019.

[5] P.M.Kohl, \& S.J.Medlar, "Occurrence of Manganese in Drinking Water and Manganese Control", American Water Works Association.2006.

[6] F. Fu, \& Q.Wang, "Removal of heavy metal ions from wastewaters: A review", Journal of Environmental Management, 92(3), 407-418, 2011.

[7] K. Budin, Y. Subramaniam, R. Tair, \& S. M.Ali, "The Ability Of Crab And Cockle Shell To Adsorb Lead And Chromium From Industrial Effluent”, IOSR J. Environ. Sci. Toxicol. Food Technol, 8, 4-6, 2014.

[8] M.Ziółkowska, J.Milewska-Duda, \& J.T.Duda, "Effect Of Adsorbate Properties On Adsorption Mechanisms: Computational Study", Adsorption, 22(4-6), 589-597, 2016.

[9] S.N.F. Moideen, M.F.M. Din, S. Rezania, M. Ponraj, A. Abd Rahman, L.W. Pei, Z. Ismail, S.M. Taib, \& D. Komori, "Dual Phase Role Of Composite Adsorbents Made From Cockleshell And Natural Zeolite In Treating River Water", Journal of King Saud University-Science, 32(1), 1-6, 2020.

[10] A.S. Ayangbenro, \& O. O.Babalola, "A new strategy for heavy metal polluted environments: a review of microbial biosorbents", International Journal Of Environmental Research And Public Health, 14(1), 94, 2017.

[11] N. Ariffin, M.M.A.B. Abdullah, M.R.R.M.A. Zainol, M.F. Murshed, M.A.Faris, \& R. Bayuaji, "Review on adsorption of heavy metal in wastewater by using geopolymer", In MATEC Web of Conferences, 97, p. 01023, 2017

[12] O.E.A.Salam, N.A. Reiad, \& M.M.ElShafei, "A Study Of The Removal Characteristics Of Heavy Metals From Wastewater By Low-Cost Adsorbents". Journal of Advanced Research, 2(4), 297-303, 2011.

[13] E. Bernard, A. Jimoh, \& J. Odigure, "Heavy Metals 
Removal from Industrial Wastewater By Activated Carbon Prepared From Coconut Shell". Res J Chem Sci, 2231, 2013.

[14] M.S.Masoud, W.M. El-Saraf, A.M.Abdel-Halim, Ali, A. E., E.A. Mohamed, \& H.M. Hasan, "Rice Husk And Activated Carbon For Wastewater Treatment Of El-Mex Bay", Alexandria Coast, Egypt. Arabian Journal of Chemistry, 9, 1590-1596, 2016

[15] E.A. Deliyanni, G.Z.Kyzas, G. Z., K.S.Triantafyllidis, \& K.A. Matis, Activated carbons for the removal of heavy metal ions: A Systematic Review Of Recent Literature Focused On Lead And Arsenic Ions. Open Chemistry, 13(1), 2015.

[16] H. Gebretsadik, A. Gebrekidan, \&L. Demlie, "Removal Of Heavy Metals From Aqueous Solutions Using Eucalyptus Camaldulensis: An Alternate Low-Cost Adsorbent", Cogent Chemistry, 6(1), 2020.

[17] N.A.Akbar, H.A. Aziz, \& M.A.Adlan, "Potential Of High-Quality Limestone As Adsorbent For Iron And Manganese Removal In Groundwater". Jurnal Teknologi, 78(9-4), 2016.

[18] M.A. Ghafar, S.Liyana, M.Z. Hussein, \& Z. Abu Bakar Zakaria, "Synthesis And Characterisation Of Cockle Shell-Based Calcium Carbonate Aragonite Polymorph Nanoparticles With Surface Functionalisation”, Journal of Nanoparticles, 2017.

[19] A. You, M.A.Y. Be, \& I. In, "Synthesis And Characterisation of $\mathrm{CaCO}_{3}$ (Calcite) Nano Particles from Cockle Shells (Anadara Granosa Linn) By Precipitation Method Synthesis And Characterisation ff $\mathrm{CaCO}_{3}$ (Calcite) Nano. 1855 (1), 1-5, 2017.

[20] S. Fathiyah, S. Mohamad, S. Mohamad, \& Z. Jemaat, "Study Of Calcination Condition On Decomposition Of Calcium Carbonate In Waste Cockle Shell to Calcium Oxide Using Thermal Gravimetric Analysis".2016.

[21] A.Linggawati, "Preparation and Characterization of Calcium Oxide Heterogeneous Catalyst Derived from Anadara Granosa Shell for Biodiesel Synthesis", KnE Engineering, 1, 1-8, 2016.

[22] Y.Tiandho, H. Aldila, M. Mustari, Megiyo, \& F. Afriani, "Utilization Of Wasted Cockle Shell As A Natural Coagulant And A Neutraliser of Polluted Water in Bangka Belitung Islands", Indonesia. Journal of Physics: Conference Series, 1013(1), 3-8, 2018.

[23] Y. Taamneh, \& S. Sharadqah, "The Removal Of Heavy Metals From Aqueous Solution Using Natural Jordanian Zeolite”, Applied Water Science, 7(4), 2021-2028, 2017.

[24] A. Omri, \& M. Benzina, "Removal of Manganese (II) Ions From Aqueous Solutions by Adsorption on Activated Carbon Derived A New Precursor: Ziziphus Spina-Christi Seeds", Alexandria Engineering Journal, 51(4), 2012.

[25] M.A.Atieh, O.Y. Bakather, B. Al-Tawbini, A.A.Bukhari, F.A. Abuilaiwi, \& M.B. Fettouhi, "Effect of Carboxylic
Functional Group Functionalized on Carbon Nanotubes Surface on The Removal Of Lead From Water", Bioinorganic Chemistry and Applications, 2010.

[26] L.J. Westholm, \& E. Repo, "Filter materials for metal removal from mine drainage- A review”, 2014.

[27] G.M. Al-Senani, \& F.F. Al-Fawzan, "Adsorption study of heavy metal ions from aqueous solution by nanoparticle of wild herbs", The Egyptian Journal of Aquatic Research, 44(3), 187-194, 2018.

[28] T. Brahmaiah,, L. Spurthi, K. Chandrika, S. Ramanaiah, \& K.S. Prasad, "Kinetics of Heavy Metal (Cr \& Ni) Removal from the Wastewater by Useing Low Cost Adsorbent", World Journal of Pharmacy and Pharmaceutical Sciences, 4(11), 1600-1610, 2015.

[29] A. Mojiri, Z.Ahmad, R.M. Tajuddin, M.F. Arshad, \& V. Barrera, "Molybdenum (VI) Removal from Aqueous Solutions using Bentonite And Powdered Cockle Shell; Optimisation By Response Surface Methodology", Global Nest Journal, 19(2), 232-240, 2017.

[30] V. Kumar, A. Sharma, P. Kaur, G.P.S.Sidhu, A.S.Bali, R. Bhardwaj, A.K. Thukral, \& A. Cerda, "Pollution Assessment of Heavy Metals In Soils of India And Ecological Risk Assessment: A State-of-The-Art", Chemosphere, 216, 449-462, 2019.

[31] N. Ayawei, A.N. Ebelegi, \& D. Wankasi, "Modelling And Interpretation of Adsorption Isotherms", Journal of Chemistry, 2017.

[32] E. Neag, A.I. Török, C. Tanaselia, I. Aschilean, \& M. Senila, "Kinetics and Equilibrium Studies for the Removal of Mn and $\mathrm{Fe}$ from Binary Metal Solution Systems Using a Romanian Thermally Activated Natural Zeolite", Water, 12(6), 1614, 2020.

[33] T.S. Khayyun, \& A.H. Mseer, "Comparison Of The Experimental Results With The Langmuir and Freundlich Models for Copper Removal on Limestone Adsorbent", Applied Water Science, 9(8), 170, 2019.

[34] F.A.Adekola, D.S.S. Hodonou, \& H.I. Adegoke, "Thermodynamic And Kinetic Studies Of Biosorption Of Iron And Manganese From Aqueous Medium Using Rice Husk Ash", Applied Water Science, 6(4), 319-330, 2016.

[35] D. Surovka, \& E. Pertile,” Sorption of Iron, Manganese, and Copper from Aqueous Solution Using Orange Peel: Optimisation, Isothermic, Kinetic, and Thermodynamic Studies", Polish Journal of Environmental Studies, 26(2), 2017.

[36] K. Wieszczycka, K. Filipowiak, I. Wojciechowska, \& P. Aksamitowski, "Novel Ionic Liquid-Modified Polymers for Highly Effective Adsorption Of Heavy Metals Ions", Separation and Purification Technology, 236, 2020.

[37] Y. Wang,X. Gao, Y. Fu, X. Wu, Q. Wang, W. Zhang, \& C. Luo, "Enhanced Microwave Absorption Performances Of Polyaniline/Graphene Aerogel By Covalent Bonding", Composites Part B: Engineering, 169, 221-228. 2019. 